\title{
HUBUNGAN TINGGI WAJAH BAWAH DENGAN LEBAR SENYUM PADA SUKU BALI DI FKG UNIVERSITAS MAHASARASWATI DENPASAR
}

\author{
Norman Hidajah, I Dewa Gede Budijanana, Dwis Syahrul, Ranny Artha Himawan \\ Bagian Ortodonti, Fakultas Kedokteran Gigi Universitas Mahasarawati Denpasar \\ E-mail: drgnorman@yahoo.com
}

\begin{abstract}
Physical attractiveness plays an important role in how we see ourselves and how we are seen by others. Individuals mainly focus on the eyes and mouth of others during interpersonal interactions. An attractive smile will create good interpersonal relationships. A perfect smile is created when there is harmony and balance between the shape of the face and teeth. Measurement of the lower anterior facial height is one of the vertical evaluations that has a close relation to a person's aesthetics and to orthodontic treatment. The width of the smile is the distance between the outer commissures of the lips. The aim of the study was to determine whether there is or no correlation between lower facial height and smile width in the Balinese at FKG Mahasaraswati Denpasar University. This study was an observational analytic study with a cross sectional design using a sample of 50 Balinese subjects aged 18-25 years at FKG Mahasaraswati Denpasar University. The sample used in this study was taken by simple random sampling technique based on inclusion and exclusion criteria. Data collecting was done by direct measurement of the sample using calipers to measure the lower facial height and the width of the smile. The results showed a significant correlation between lower facial height and smile width with a significance value of $0.028(p \leq 0.05)$ and a correlation coefficient of 0.312 . A positive correlation indicates that the greater the lower facial height value, the greater the smile width value tends to be.
\end{abstract}

Keywords: smile, lower facial height, smile width.

\section{PENDAHULUAN}

Senyum yang menarik akan menciptakan hubungan interpersonal yang baik sehingga membuat seorang individu lebih diterima di lingkungan sosialnya. Secara umum, senyum dapat didefinisikan sebagai perubahan ekspresi fasial pada seseorang, yang melibatkan mata dan komisura bibir, serta tidak menghasilkan suara. Pada dasarnya ada dua tipe senyum, yaitu senyum sosial (posed smile) dan senyum spontan (unposed smile). Senyum sosial yaitu senyum yang banyak digunakan untuk mengungkapkan salam, terjadi dengan sukarela, tanpa paksaan serta memberikan kesan ramah. Senyum spontan terjadi akibat tertawa atau perasaan sangat senang. Senyum sosial lebih banyak diterapkan dalam aktivitas sosial sehari-hari sehingga sering menjadi dasar bagi ortodontis dalam penetapan diagnosis ${ }^{1}$.

Senyum yang sempurna tercipta ketika ada keselarasan dan keseimbangan antara bentuk wajah dan gigi. Untuk membentuk senyum yang ideal memerlukan analisis dan evaluasi terhadap wajah, bibir, jaringan gingiva, bentuk, warna gigi dan kombinasi dari komponen tersebut ${ }^{2}$.

Permasalahan vertikal wajah memiliki keterkaitan terhadap tinggi wajah anterior bawah seseorang. Tinggi wajah anterior bawah atau LAFH (Lower Anterior Facial Height) adalah jarak vertikal diantara anterior nasal spine dan menton. Pengukuran terhadap tinggi wajah anterior bawah merupakan salah satu evaluasi vertikal yang memiliki kaitan erat terhadap estetika seseorang maupun terhadap perawatan ortodonti. Lebar senyum merupakan salah satu komponen dalam mengukur estetika. Lebar senyum merupakan jarak antara komisura luar bibir ${ }^{3}$.
Komponen pembentuk dimensi vertikal wajah adalah pertumbuhan maksila dan mandibula serta perkembangan prosesus alveolaris sebagai akibat dari erupsi gigi geligi. Faktor yang membedakan pertumbuhan dan perkembangan dentokraniofasial dan fisik seorang individu salah satunya terdapat pada ras.

Penduduk Indonesia terdiri dari berbagai macam ras. Ras merupakan salah satu faktor yang dapat mempengaruhi pertumbuhan, hal ini terlihat dari adanya tipe wajah yang berbeda-beda antar ras yang ada. Kelompok ras yang berbeda akan memperlihatkan pola pertumbuhan kraniofasial yang berbeda sehingga mempunyai kecenderungan untuk memiliki pola bentuk tengkorak dan rahang tertentu, walaupun pola semacam ini dipengaruhi oleh variasi individu ${ }^{4}$.

Berdasarkan uraian diatas, peneliti tertarik untuk melakukan penelitian lebih lanjut mengenai hubungan tinggi wajah bawah dengan lebar senyum pada suku Bali di FKG Universitas Mahasaraswati Denpasar.

\section{BAHAN DAN METODE}

Alat dan bahan

Alat yang digunakan berupa Jangka sorong, kaca mulut, masker, handscone, nearbecken, alat tulis, dan kursi.

Rancangan penelitian pada penelitian ini adalah analitik observasional dengan desain cross sectional yang merupakan studi untuk mengukur variabel secara bersamaan pada waktu tertentu ${ }^{5}$. Populasi dari penelitian ini adalah mahasiswa suku Bali Fakultas Kedokteran Gigi Universitas Mahasaraswati Denpasar berusia 18 - 25 tahun sebanyak 97 orang.

Tahapan penelitian 
Tahapan penelitian yang dilakukan berdasarkan kriteria inklusi dan eksklus, sampel yang sesuai diberikan lembar informed consent, mengukur tinggi wajah bawah subjek diinstruksikan untuk oklusi. kemudian tinggi wajah bawah diukur dengan menggunakan jangka sorong dari dasar hidung ke dagu.

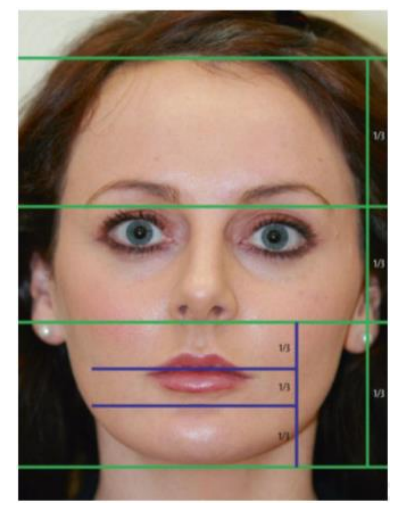

Gambar 1. Facial Thirds

mengukur lebar senyum (subjek diinstruksikan untuk senyum sosial dengan mengucapkan kata cheese). diukur dengan menggunakan jangka sorong dari komisura luar bagian kiri ke komisura luar bagian kanan bibir.

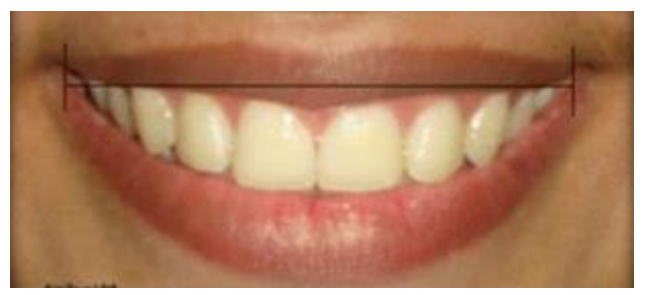

Gambar 2. Lebar Senyum

Catat hasil pengukuran pada form yang telah tersedia.

\section{HASIL DAN PEMBAHASAN}

Penelitian dilakukan pada mahasiswa suku Bali di FKG Universitas Mahasaraswati Denpasar yang berusia 18-25 tahun yang memenuhi kriteria. Subjek diukur langsung dengan menggunakan jangka sorong untuk mendapatkan tinggi wajah bawah dan lebar senyum. Untuk mendapatkan hasil yang akurat, dilakukan tiga kali pengukuran untuk tinggi wajah bawah dan lebar senyum pada setiap subjek.

Tabel 1. Distribusi responden berdasarkan tinggi wajah bawah

\begin{tabular}{cccc}
\hline $\mathrm{N}$ & $\begin{array}{c}\text { Minimum } \\
(\mathrm{mm})\end{array}$ & $\begin{array}{c}\text { Maksimum } \\
(\mathrm{mm})\end{array}$ & Mean \pm Std \\
\hline 50 & 53,70 & 79,06 & $65,10 \pm 5,29$ \\
\hline
\end{tabular}

Tabel 1 menunjukkan bahwa tinggi wajah minimum pada responden adalah $53,70 \mathrm{~mm}$ dan tinggi wajah maksimum pada responden adalah 79,06 mm.

Tabel 2. Distribusi responden berdasarkan lebar senyum $\mathrm{N}$ Minimum Maksimum $\quad$ Mean \pm Std

\begin{tabular}{llll}
\hline & $(\mathrm{mm})$ & $(\mathrm{mm})$ & \\
\hline 50 & 51,50 & 71,58 & $61,61 \pm 5,21$ \\
\hline
\end{tabular}

Tabel 2 menunjukkan bahwa lebar senyum minimum pada responden adalah $51,50 \mathrm{~mm}$ dan tinggi wajah maksimum pada responden adalah 71,58 mm.

Analisis hubungan tinggi wajah bawah dengan lebar senyum dilakukan uji Korelasi Pearson

Tabel 3. Hasil Uji Korelasi Pearson Tinggi Wajah Bawah dengan Lebar Senyum pada Suku Bali di FKG Universitas Mahasaraswati Denpasar

\begin{tabular}{|c|c|c|c|c|}
\hline & & & $\begin{array}{l}\text { Tinggi } \\
\text { Wajah } \\
\text { Bawah }\end{array}$ & $\begin{array}{c}\text { Lebar } \\
\text { Senyum }\end{array}$ \\
\hline \multirow{6}{*}{ Pearson } & Tinggi & Correlation & 1.000 & .312 \\
\hline & Wajah & Coefficient & . & .028 \\
\hline & Bawah & $\begin{array}{l}\text { Sig. (2- } \\
\text { tailed) } \\
\mathrm{N}\end{array}$ & 50 & 50 \\
\hline & Lebar & Correlation & .312 & 1.000 \\
\hline & Senyum & Coefficient & .028 & \\
\hline & & $\begin{array}{l}\text { Sig. (2- } \\
\text { tailed) } \\
\mathrm{N}\end{array}$ & 50 & 50 \\
\hline
\end{tabular}

Dari hasil penelitian yang telah dilakukan, didapatkan hasil bahwa terdapat hubungan yang signifikan antara tinggi wajah bawah dengan lebar senyum pada suku Bali di FKG Universitas Mahasaraswati Denpasar.

Hasil penelitian ini sejalan dengan hasil penelitian yang dilakukan Abraham dkk. tentang rasio antara lebar senyum dengan tinggi wajah bawah pada penduduk India bagian selatan ${ }^{6}$.

Penelitian yang dilakukan Ally (2018) juga menunjukan adanya hubungan yang signifikan antara tinggi wajah bawah dengan lebar senyum dengan nilai koefisien korelasi sebesar 0,322. Adanya hubungan antara tinggi wajah bawah dengan lebar senyum dapat terjadi karena pertumbuhan mandibula cenderung mengikuti pertumbuhan maksila. Pertumbuhan maksila secara berurutan lebih dominan terhadap tinggi, kedalaman, dan lebar, sedangkan pertumbuhan mandibula cenderung mengalami pertambahan tinggi dan lebar ${ }^{7}$.

Penelitian yang dilakukan oleh Abraham dkk. (2015) menyatakan bahwa rasio estetika antara tinggi wajah bawah dengan lebar senyum akan menjadi parameter baru dalam evaluasi wajah dan senyum. Kehilangan dimensi vertikal pada pasien dengan atrisi kronis seperti pada bruxism atau kebiasaan parafungsional lainnya dapat mengambil manfaat dari temuan ini karena lebar senyum pada pasien tersebut dapat digunakan sebagai panduan dalam memulihakan dimensi vertikal yang hilang. Dalam bidang ortodontik, parameter ini dapat digunakan dalam menentukan besarnya bite opening dalam kasus gigitan dalam. Dari perspektif bedah ortognatik, rasio ini mungkin membantu dalam menentukan tinggi wajah bawah 
dalam defisiensi vertikal maksila dan meningkatkan posisi inferior maksila, tetapi studi lebih lanjut diperlukan untuk memvalidasi ini. Selain itu, rasio ini dapat ditambahkan sebagai faktor baru dalam evaluasi estetika senyum.

Adanya hubungan antara tinggi wajah bawah dengan lebar senyum dapat terjadi karena pertumbuhan mandibula cenderung mengikuti pertumbuhan maksila. Pertumbuhan maksila secara berurutan lebih dominan terhadap tinggi, kedalaman, dan lebar, sedangkan pertumbuhan mandibula cenderung mengalami pertambahan tinggi dan lebar ${ }^{6}$.

Tulang maksila terhubung dengan tulang palatum melalui suatu sutura yang memberi kesempatan pada tulang untuk berkembang dan berkontak dengan tulang di sekitarnya. Sutura membuat maksila dan palatum bergerak ke depan dan ke bawah terhadap basis kranium anterior selama masa pertumbuhan. Lengkung maksila menjadi lebih tinggi dan lebih lebar akibat pertumbuhan. Seiring pertumbuhan maksila yang meninggi dan melebar, senyum menjadi lebih sempit secara vertikal dan melebar secara horizontal ${ }^{8}$.

\section{SIMPULAN}

Berdasarkan hasil penelitian yang telah dilakukan dapat disimpulkan bahwa terdapat hubungan yang signifikan antara tinggi wajah bawah dengan lebar senyum pada suku Bali di FKG Universitas Mahasaraswati Denpasar.

\section{UCAPAN TERIMA KASIH}

Penulis mengucapkan terima kasih kepada Tuhan Yang Maha Esa dan pihak yang telah membantu dalam penyelesaian artikel ini

\section{DAFTAR PUSTAKA}

1. Monica, G.A., 2007, 'Gambaran Senyum Pasien Pasca Perawatan Ortodonsia (Kajian Foto Frontal)', Indonesian J of Dent 14(2), hal. 136145.

2. Nurfitrah, A., Christnawati, C. \& Alhasyimi, A.A., 2017, 'Comparison of esthetic smile perceptions among male and female Indonesian dental students relating to the buccal corridors of a smile', Dental Journal, vol 50(3), hal. 127-130, Fakultas Kedokteran Gigi, Universitas Gajah Mada, Yogyakarta.

3. Maganzini, A.L., Schroetter, S.B., Freeman, K., 2014, 'Improvement in smile esthetics following orthodontic treatment A retrospective study utilizing standardized smile analysis', Angle Orthodontist 84(3), hal. 492-499.

4. Sudarso, I., 2003, 'Perbedaan Pengaruh Ukuran Mesiodistal Gigi Desidui Rahang Atas terhadap Bentuk Lengkung dan Wajah Anak Arah Lateral pada Anak Perempuan Suku Jawa dengan Cina Umur 5-6 tahun', Jurnal Kedokteran Gigi, Jakarta : Universitas Indonesia.

5. Roeslan, B.O., 2003, Metodologi Penelitian Bidang Kesehatan, Abadi Dhaya Insani, Jakarta.

6. Abraham, A., George, J., Peter, E., Philip, K., Chankramath, R., Johns, D.A., Bhaskar, A., 2015, 'Establishment of a new relationship between posed smile width and lower facial height: A cross-sectional study', European J of Dent, vol 9(3).

7. Ally, S., 2018, 'Hubungan Tinggi Wajah Bawah dengan Lebar Senyum pada Ras Proto-melayu di Kota Medan', Skripsi, Fakultas Kedokteran Gigi, Universitas Sumatera Utara.

8. Sharma, P., Arora, A. \& Valiathan, A., 2014, 'Age Changes of Jaws and Soft Tissue Profile', Sci World J. 